\title{
Geneza wyższych szkół pedagogicznych i ich rozwój organizacyjny w latach 1946-1949
}

Utworzone w 1946 roku wyższe szkoły pedagogiczne weszły na trwałe do struktury systemu szkolnictwa wyższego w Polsce. Do dnia dzisiejszego skutecznie też uzupełniają ofertę kształceniową uniwersytetów ${ }^{1}$, wykazując w wielu przypadkach duży dynamizm i prężność w zakresie podejmowanych badań naukowych. Specjalizując się zasadniczo w kształceniu nauczycieli spełniają też one ważną rolę kulturotwórczą, szczególnie istotną dla miast i regionów pozbawionych wlasnych uniwersytetów i innych uczelni wyższych. Mając na uwadze powyższe uwarunkowania warto przypomnieć genezę wyższych szkół pedagogicznych oraz prześledzić ich rozwój organizacyjny w latach 1946-1949, a więc w okresie, w którym ich zasadniczym zadaniem było kształcenie nauczycieli dla najwyżej zorganizowanych szkół powszechnych (podstawowych).

Zagadnienie to wydaje się tym ważniejsze, że choć w chwili swych narodzin wyższe szkoły pedagogiczne były nowym, nieznanym ogniwem systemu kształcenia nauczycieli w Polsce, to ich idea w sposób naturalny wyrasta $\mathrm{z}$ aspiracji postępowego nauczycielstwa polskiego, współtworzqcego ruch pedagogiczny na ziemiach polskich w okresie zaborów ${ }^{2}$. Ich odzwierciedleniem był m.in. opracowany przez Jana Wladyslawa Dawida ${ }^{3}$ projekt Polskiego Instytutu Pedagogicznego, w którym - w myśl założeń jego twórcy - nauczyciele szkół ludowych mogliby ukończyć studia wyższe, zaś nauczyciele szkół średnich zdobyć wykształcenie pedagogiczne i dydaktyczne ${ }^{4}$. Problem wyższego wykształcenia nauczycieli szkół powszechnych był także szeroko omawiany na kolejnych zjazdach nauczycielskich. Odbiciem stanowiska delegatów stowarzyszeń nauczycielskich, zarówno z Królestwa, jak i z Poznańskiego oraz Galicji były m.in. propozycje zgłaszane przez Henryka Rowida ${ }^{5}$. Wypowiadając się na temat kształcenia nauczycieli szkół powszechnych postulowal on, by okres ich edukacji wydhużyc do trzynastu - czternastu lat, z których siedem lat nauki przypadałoby na kształcenie w szkole powszechnej, cztery lata - w szkole średniej i dwa lub trzy lata - w seminarium nauczycielskim o charakterze wyższej szkoły zawodowej ${ }^{6}$. Zasadnicze tezy tej koncepcji przyjęto też w uchwale zjazdowej Ogólnopolskiego Wielkiego Zjazdu Nauczycielskiego ${ }^{7}$, obradującego w 1919 r. w Warszawie ${ }^{8}$.

\footnotetext{
${ }^{1}$ Regułą stała się sytuacja, w której wyższe szkoły pedagogiczne, osiągnąwszy odpowiednio wysoki poziom naukowy, wspóltworzyły podstawy nowo kreowanych uniwersytetów. Tak bylo w przypadku WSP w Katowicach, WSP w Gdańsku, WSP w Opolu, WSP w Szczecinie, a ostatnio także WSP w Olsztynie. Wyjątkiem od tej zasady jest WSP w Krakowie, która w 1999 roku przekształciła się w Akademię Pedagogiczną.

${ }^{2}$ Por.: J. Miąso, Zwiazki nauczycielskie i naukowy ruch pedagogiczny, „Przegląd Historyczno-Oswiatowy" 1985 , or 2 (108), s. $204-212$.

3 "Ruch Pedagogiczny" 1913, nr 4, Przedruk w: W. Okon', Dawid, Warszawa 1980, Por.: S. Woloszyn, Jano Wadyslawa Dawida program ksztalcenia nauczycieli - pedagogów, „Kwartalnik Pedagogiczny" 1960 , nr 3.

4 R. Dutkowa, Studium Pedagogiczne Uniwersytetu Jagiellonskiego 1921-1952, „Przegląd Historyczno-Oświatowy" 1968, nr 4(42), s. 447.

5 Zasadnicze założenia swego programu kształcenia nauczycieli przedstawił H. Rowid na zjeździe delegatów 40 organizacji nauczycielskich z Królestwa, z udziałem przedstawicieli nauczycielstwa z Galicji, który odbyl się w Radomiu w dniach 28 -30 grudnia 1916 r. Por.: A. Szumski, Walka Henryka Rowida o ksztalcenie nauczycieli szkól powszechnych w uczelniach wyższych, "Studia Pedagogiczne" 1978, t. XXXIX, s. $121-122$.

$6 \mathrm{~S}$. Woloszyn, Zwiqzkowy ruch nauczycieli wobec ksztalcenia $i$ doskonalenia nauczycieli (kartki z przeszlosci), „Przegląd Historyczno-Oświatowy" 1985, nr 3-4 (108/109), s. 340.

"Por.: S. Mauersberg Sejm Nauczycielski (14-17 kwietnia 1919 r.), „Rozprawy z Dziejów Oswiaty" 1980, t. XXIII.

0 szkole polskq. Pierwszy Ogólnopolski Welki Zjazd w dniach od 14 do 17 kwietnia 1919 r., Lwów - Warszawa 1918-1920; Por. także: P. Bródka, Z dziejów walki o wyksztalcenie wyższe nauczycieli szkoly powszechnej, „Przegląd Historyczno-Oświatowy" 1969, nr 2 (44), s. 175.
} 
Nie wszystkie z inicjatyw zgłaszanych u progu odzyskania niepodległości przez Polskę doczekały się realizacji w latach 1918 - 1939. Szansę taką dostala lansowana przez H. Rowida idea 2-letnich pedagogiów. Pod naciskiem organizacji nauczycielskich, w 1928 roku Ministerstwo Wyznań Religijnych i Oświecenia Publicznego zatwierdziło „Statut Państwowych Pedagogiów". W ślad za tym doszło do otwarcia pierwszych tego typu placówek w Krakowie, Warszawie i Lublinie ${ }^{10}$. Właściwe warunki dla ich rozwoju stworzyła jednak dopiero ustawa 11 marca 1932 roku ${ }^{11}$. Utworzenie państwowych pedagogiów nie zaspokajało jednak oczekiwań nauczycielstwa, domagającego się kształcenia nauczycieli szkół powszechnych na poziomie wyższym. Przy tym utworzony w 1930 r. Związek Nauczycielstwa Polskiego [ZNP], sceptycznie odnosząc się do możliwości właściwego przygotowania nauczycieli szkół powszechnych $w$ „skłonnych do zbytniego teoretyzowania" uniwersytetach, opowiadał się za utworzeniem nowego typu uczelni - akagdemii pedagogicznych ${ }^{12}$. Wobec niemożności realizacji tego postulatu przez Ministerstwo Wyznań Religijnych i Oświecenia Publicznego, ZNP w roku 1932 powołał do życia Instytut Pedagogiczny w Warszawie, pomyślany jako wyższa uczelnia nauczycielska typu korespondencyjno-stacjonarnego ${ }^{13}$. Instytut ten, a także działający od $1928 \mathrm{r}$. Instytut Pedagogiczny w Katowicach ${ }^{14}$ oraz państwowe pedagogia, wypracowały w okresie mięzywojennym praktyczny model kształcenia czynnych nauczycieli szkół powszechnych na poziomie studiów wyższych. Stały się zatem, obok wspomnianego projektu Instytutu Pedagogicznego J. W. Dawida, pierwowzorem wyższych szkół pedagogicznych.

Idea tych specyficznych uczelni uksztaltowala się ostatecznie po zakończeniu II wojny światowej. Nie nastąpiło to jednak tak szybko, jakby sobie tego życzyli działacze nauczycielscy. Podstawowym zadaniem władz w Polsce po 1945 roku stała się bowiem odbudowa oświaty. Jej sytuacje, poza stratami materialnymi, komplikowały jednak przemiany społeczno-polityczne, zachodzące w Polsce (począwszy od połowy 1944 r.) przy czynnym udziale Polskiej Partii Robotniczej (PPR) i aktywnym poparciu ZSRR. Odpowiedzia na terror Armii Czerwonej ${ }^{15}$ i represje, dotykające m.in. pracowników oświaty i kultury na obszarach wyzwolonych spod okupaçi hitlerowskiej ${ }^{16}$ były nieufność (a w wielu przypadkach czynny opór) zwolenników zachowania ciągłości państwa polskiego na podstawie realiów, ukształtowanych $w$ okresie międzywojennym, uznających legalność rządu emigracyjnego w Londynie. Równolegle postępował proces rozpadu nie tylko systemu instytucji i organizacji, wytworzonych w okresie dwudziestolecia, ale też wzorów myślenia i postępowania oraz ukształtowanej wówczas struktury klasowej ${ }^{17}$. Sytuacja oświaty dodatkowo skomplikowała się po sfałszowanych wyborach do Sejmu w styczniu

${ }^{9}$ Dz. Urz. Min. WRiOP, 1928, nr 8.

10 Były to pierwsze pedagogia, kształcq̨ce kandydatów na nauczycieli szkół powszechnych w oparciu o statut z 1928 r. W latach 1928 - 1939 utworzono kolejne: w Poznaniu, Toruniu, Katowicach, Lwowie, Wilnie, Lodzi, Plocku i Krzemieńcu. Por.: J. Hellwig, Drialalność Paristwowego Pedagogium w Poznaniu (1937-1947), "Przegląd Historyczno-Oswiatowy" 1980, nr 1 (87), \&. 62 i dalsze.

11 Dz.U. R.P. , 1932, ar 38, art. 40-41.

12 J. Kulpa, Problem ksztalcenia nauczycieli na poziomie akademickim w polskiej teorii i praktyce pedagogicznej, w: Ksztalcenie nauczycieli w Wyższej Szkole Pedagogicznej. Konferencja naukowa ku uczczeniu 15-lecia Wyższej Szkoly Pedagogicznej w Krakowie 1946-1961, Kraków 1962, s. 19.

${ }_{13} \mathrm{~S}$. Woloszyn, Z najpiękniejszych tradycji Zwiqzku Nauczycielstwa Polskiego w ksztalceniu $i$ doskonaleniu zawodowym nauczycieli, „Studia Pedagogiczne” 1978, t.. XXXIX, s. 149.

14 Por. min.: Instytuty pedagogiczne Zwiqzku Nauczycielstwa Polskiego, pod red. B. Suchodolskiego, Warszawa 1972, J. Hellwig Wklad Zwiqzku Nauczycielstwa Polskiego w ksztalcenie i doksztalcanie nauczycieli w Polsce (1918-1968), Poznań 1973, J. Pieter, Czasy i ludzie, cz. II, Toruń 1997.

${ }^{15}$ Jego odzwierciedleniem byly m.in. aresztowania przez NKWD ujawniających sie oddzialów Armii Krajowej, a także prześladowania $i$ aresztowania, łącznie z deportacją do ZSRR, przedstawicieli administracj podziemnego państwa polskiego. Por. B. Potyrała, Srodowiska nauczycielskie w Polsce w pierwszym powojennym dziesięcioleciu, „Przegląd Historyczno-Oświatowy" 1991, nr 3-4 (133-134), \&. 149-167.

${ }_{16}$ Por. B. Grzes, Motywacje prawno-polityczne represjonowania pracownikow oswiaty $i$ nauki w latach 1944 -1956, „Przegląd Historyczno-Oświatowy" 1998, nr 3-4, s. $271-282$.

${ }^{17}$ Por.: J. Szczepański, Zmiany struktury klasowej w Polsce $i$ ich wplyw na inteligencje, w: Wyksztalcenie a pozycja spoleczna inteligencji. Cz. II. Pod red. J. Szczepanskiego, Lódź - Warszawa 1960, s. 456-462. 
1947 r., które dały PPR pelnię władzy w kraju. W następstwie tego przystąpila ona do urzeczywistniania zasadniczych celów swego programu politycznego. Ponieważ ich realizacja wymagała udziału szkoły, PPR w krótkim czasie ustaliła własne priorytety oświatowe, nakreśliła nowe ideały wychowawcze $\mathrm{i}$ wynikajace $\mathrm{z}$ nich cele ksztalcenia $\mathrm{i}$ wychowania. W ślad za tym opracowano też nowe programy kształcenia i wychowania ${ }^{18}$.

Rozwiązania wymagał też problem kadr nauczycielskich. Znaczne straty osobowe ${ }^{19}$, poniesione przez nauczycielstwo polskie wszystkich szczebli w okresie wojny $\mathrm{i}$ okupacji, spotęgowane zostały tuż po wojnie przez odpływ nauczycieli do innych, lepiej płatnych zawodów. Ponadto wielu nauczycieli, związanych w okresie okupacji z rządem londyńskim, pomimo skierowanego do nich wezwania kierownika resortu oświaty $\mathrm{PKWN}{ }^{20}$, zachęcającego do dołożenia wszelkich starań dla odbudowy „gmachu oświaty w Polsce", nie chciało po 1945 r. podejmować pracy w szkołach, podporządkowanych władzom komunistycznym ${ }^{21}$. Stąd też, współuczestnicząc w tworzeniu nowych szkół, odmawiali zazwyczaj współpracy z reprezentantami rządu w Lublinie ${ }^{22}$. Innym powodem wzrostu zapotrzebowania na kadry nauczycielskie była zmiana zasad organizacji szkół powszechnych. Proces ten generalnie zmierzał do tego, aby w terenie przekształcać szkoły powszechne I stopnia w szkoły niepełne, realizujące program odpowiednio: trzech, czterech, pięciu lub sześciu jednorocznych klas szkoły III stopnia ${ }^{23}$.

Doraźnym rozwiązaniem problemów kadrowych oświaty stało się zatrudnianie w szkołach nauczycieli niekwalifikowanych, głównie absolwentów różnorodnych kursów pedagogicznych. Otwarte pozostawało jednak pytanie o docelowe rozwiązanie kryzysu kadrowego szkolnictwa na drodze ksztalcenia nowych kadr nauczycielskich. Zadanie to było tym trudniejsze, że po zakończeniu II wojny światowej odżyły niespełnione postulaty posteppowych działaczy oświatowych $z$ okresu międzywojennego, dotyczące kształcenia nauczycieli szkół powszechnych na poziomie wyższym. W takich warunkach, na mocy Zarządzenia Kierownika Resortu Oświaty z dnia 12 sierpnia $1944 \mathrm{r}^{24}$, uruchomiono pierwsze zakłady kształcenia nauczycieli: licea pedagogiczne i pedagogia, nawiązując tym samym do rozwiązań, przyjętych w Ustawie z 11 marca 1932 r. Podtrzymano również ważność przedwojennych zarządzeń w sprawie naboru uczniów do tych szkół ${ }^{25}$. Z treścią tego postanowienia korespondowały uchwały delegatów Ogólnopolskiego Zjazdu凶Oświatowego w Lodzi z czerwca $1945 \mathrm{r}^{26}$, zalecające władzom oświatowym wprowadzenie 8-klasowej, obowiązkowej i jednolitej pod względem programowym szkoły powszechnej na wsi i w mieście. Praktyczna realizacja tej koncepcji, określanej mianem pierwszej reformy szkolnej w Polsce po 1945 r., wymagała odpowiednio przygotowanych nauczycieli. Projekt Ministerstwa Oświaty, przedstawiony na Zjeździe przez Naczelnika Wydziału Kształcenia Nauczycieli, Edwarda Czemichowskiego, przewidywał, że nauczycieli dla szkolnictwa powszechnego powinny kształcić 3-letnie licea pedagogiczne oraz 2-letnie pedagogia, ukończenie których miało przygotowywać przede wszystkim do pracy w klasach VI - VIII szkoły ogólnokształcącej. Pedagogia miały pełnić rolę wyższych szkół nieakademickich, stąd zaproponowano dla nich nazwę: „wyższa szkoła kształcenia nauczycieli" ${ }^{27}$.

18 S. Mauersberg, Reforma szkolnictwa w Polsce w latach 1944-1948, Wrockaw 1974, s. 180.

19 Por. m.in. M. Falski, Straty Polski na polu oswiaty w okresie drugiej wojny światowej $i$ okupacji, ,Studia Pedagogiczne" 1973, t. XXVII, s. 26-42; M. Walczak, Obraz statystyczny strat $i$ mart yrologil nauczycieli polskich w okresie okupacji 1939-1945, „Przegląd Historyczno-OŚwiatowy” 1988, nr 1.

20 Por.: Wezwanie do Nauczycielstwa Polskiego Resortu Oświaty PKWN z 1 sierpnia 1944 r., Dziennik Urzędowy Resortu Oświaty (dalej: Dz. Urz. Res. Ośw.), Lublin, 30 XII 1944, nr 1-4.

${ }^{21}$ R. Zambrowski, O masowq milionowq Partie, I Zjazd PPR, 1946, 8. 42.

22 Z. Marciniak, Pierwszy rok szkolny w Polsce Ludowej, „Przegląd Historyczno-Oświatowy” 1969, nr 3 (45), s. $267-269$.

${ }^{23}$ M. Pecherski, Szkola ogólnoksztalcqua w Polsce Ludowej, Wroclaw - Warszawa - Kraków 1970, s. 65 - 66.

24 Dz. Urz. Res. Ośw. 1944, nr 1-4, poz. 5.

${ }^{25}$ Dziennik Urzędowy Ministerstwa Wyznań Religijnych i Oswiecenia Publicznego (dalej: Dz. Urz. MWRiOP) 1937, nr 3, poz 60; Dz. Urz. MWRiOP, 1928, nr 8, poz. 135.

${ }_{26}$ Ogólnopolski Zjazd Oswiatowy w Lodzi, 18-22 czerwca 1945, Warszawa 1945.

${ }^{27}$ Ibidem, 8. 215 i następne. 
Odtworzenie przedwojennej struktury systemu kształcenia nauczycieli, a w nim pedagogiów nie oznacza, ze władze oświatowe po $1945 \mathrm{r}$. wiązały z nimi większe nadzieje. Opinie o nich były bowiem zróżnicowane, w większości jednak dość krytyczne. Warto w związku z tym uwypuklić, że pedagogia, będąc doskonalszą (w stosunku do seminariów nauczycielskich i liceów pedagogicznych) formą kształcenia nauczycieli, posiadały szereg zalet. Zapewniały one bardziej gruntowne i szersze przygotowanie kandydatów, zarówno w zakresie przedmiotów ogólnokształcących, jak i zawodowych. Ponieważ naukę w pedagogiach podejmowała miodzież po pełnej szkole średniej ogólnokształcącej, w trakcie studiów istniała możliwość położenia większego nacisku na zagadnienia pedagogiczne i społeczne. $Z$ tego samego powodu pedagogia stwarzały możliwość pogłebienia wiedzy słuchaczy z zakresu fakultatywnego przedmiotu specjalizacji (przedmiotu naukowego). Miał on za zadanie rozwijać zainteresowania naukowe kandydata oraz zaznajamiać go $\mathrm{z}$ metoda pracy naukowej grupy przedmiotów obranej specjalizacji1 ${ }^{28}$. Ponadto większa dojrzałość umysłowa słuchaczy pedagogiów umożliwiała oparcie działalności dydaktycznej na ich samodzielnej pracy nad soba, pracy badawczej w środowisku, w pracowniach, laboratoriach i bibliotekach.

Pedagogia miały też jednak poważne wady. Przede wszystkim stanowily nieokreślony typ uczelni. Nie były one bowiem już szkołami średnimi, ale swoim programem i zakresem studiów nie dorównywały szkołom wyższym. Co gorsza, na tle wprowadzonej Ustawą z 1932 r. struktury szkolnictwa, pedagogia były typową „ślepq uliczką" dla swych wychowanków. Przyjęte rozwiq̨zania organizacyjne powodowały, że pedagogia nie były atrakcyjnymi zakładami kształcenia nauczycieli. Ponadto $w$ pedagogiach dość radykalnie zmieniła się - w stosunku do seminariów nauczycielskich - struktura społeczna uczniów. Systematycznie obniżał się w nich odsetek uczniów ze środowiska wiejskiego. Grupowały one też znacząco wyższy odsetek kobiet, które w roku 1938 stanowiły ponad $70 \%$ ogółu ich uczniów ${ }^{29}$. Atrakcyjność pedagogiów obniżały również duże wymagania, stawiane kandydatom, niejasna perspektywa uzyskania pracy oraz stosunkowo wysokie czesne przy niewielkich szansach na uzyskanie stypendium. Słabości pedagogiów sprawiły, że już w okresie międzywojennym ich twórca, a zarazem dyrektor Państwowego Pedagogium w Krakowie, Henryk Rowid zaproponował przedłużenie w nich okresu nauki do lat trzech, nadanie im uprawnień szkół wyższych $\mathbf{i}$ zmianę nazwy na instytuty pedagogiczne ${ }^{30}$.

Los pedagogiów przesądziła II wojna światowa i wywołane nią zmiany społeczne, polityczne i gospodarcze w Polsce. Stąd też, reaktywując je w 1944 roku traktowano pedagogia jako przejściową formę zakładu kształcenia nauczycieli. Spośród 11 tego typu zakładów, istniejących przed rokiem $1939^{31}$, odtworzono placówki, funkcjonujące w Warszawie, Lodzi, Kielcach, Poznaniu, Katowicach i Krakowie. Natomiast dawne Państwowe Pedagogium w Toruniu przeniesiono do Gdańska. Ostatecznie więc w 1945 roku ukształtowała się nowa, skromniejsza w stosunku do przedwojennej, sieć pedagogiów, którq tworzyło 7 placówek. W okresie powojennym pedagogia umożliwiały przede wszystkim dokończenie nauki tym słuchaczom, którzy rozpoczęli ją przed wybuchem II wojny światowej ${ }^{32}$.

Równolegle do działań, mających na celu odbudowę szkolnictwa polskiego w nowych uwarunkowaniach społecznych, gospodarczych, a także i geograficznych, podjęto prace nad reformą systemu kształcenia nauczycieli. W krótkim czasie zaawansowano przygotowania do powołania nowej, w założeniach jej twórców doskonalszej, formy zakładu kształcenia nauczycieli

2 M. Maciaszek, Idea ksztalcenia nauczycieli na poziomie wyższym, „Nowa Szkoła” 1957, nr 5, s. 385.

29 Por.: J. Starościak, 0 wlasciwy system ksztalcenia nauczycieli w Polsce, w: Materialy z konferencji Sekcji Zakladów Ksztalcenia Nauczycieli ZNP w dniach 26-27 listopada 1948 r., Archiwum Zarządu Głównego ZNP w Warszawie (dalej: AZG ZNP), J. Hellwig, Dzialalnośc Państwowego Pedagogium w Poznaniu, s. 73.

${ }^{30}$ M. Maciaszek, dz cyt., s. 386.

31 Państwowe Pedagogia funkcjonowały w Warszawie, Krakowie, Lublinie, Poznaniu, Katowicach, Kielcach, Lodzi, Lwowie, Plocku, Toruniu i Wilnie.

32 Z. Ruta, Pedagogia, wyższe kursy nauczycielskie, instytuty pedagogiczne, w: Ksztalcenie nauczycieli w Polsce Ludowej (1945-1977), Kraków 1983, s. 69. 
- wyższych szkół pedagogicznych. Ich koncepcje w znacznej mierze wykreował Edward Czernichowski, który już w styczniu 1945 r. zapowiedział rychłe przekształcenie pedagogiów w wyższe szkoły pedagogiczne ${ }^{33}$.

Utworzenie pierwszych wyższych szkół pedagogicznych poprzedziły wielomiesięczne prace koncepcyjne i organizacyjno-programowe. Ich zwieńczeniem było Zarządzenie Ministra Oświaty z dnia 12 marca 1946 roku w sprawie Statutu Państwowych Wyższych Szkół Pedagogicznych ${ }^{34}$. Precyzowało ono, że projektowane wyższe szkoły pedagogiczne mają na celu ksztalcenie zawodowe na poziomie wyźszym kandydatów na nauczycieli szkół powszechnych. Cel ten miały one realizować przez odpowiednią organizację i program nauki, wychowawcze oddziaływanie na słuchaczy $w$ duchu ideologii demokratycznej, właściwą organizację praktyki pedagogicznej oraz „zaprawianie” sluchaczy do twórczej pracy naukowej w dziedzinie nauk pedagogicznych. Statut stwierdzal, iż dyplom ukończenia WSP daje kwalifikacje zawodowe do nauczania w szkole powszechnej oraz „uprawnienia zwiazzane (...) z posiadaniem wykształcenia szkoły wyższej".

Wyższa szkoła pedagogiczna miała być 3-letnią szkolą wyższą nieakademicka, z założenia dążącą do współpracy ze szkołami akademickimi; korzystającą z ich sił profesorskich, a także urządzeń, instytucji, itp. Wzorem innych zakładów kształcenia nauczycieli, przewidywano funkcjonowanie przy niej szkoły ćwiczeń, składającej się z przedszkola, pełnej szkoły podstawowej i szkoły średniej. W miare potrzeb, dla realizacji ćwiczeń praktycznych WSP miała też korzystać z innych szkół wyznaczanych przez władze szkolne. W trosce o wysoka jakość przygotowania absolwentów WSP Statut zalecał by nauczycielami szkoły ćwiczeń zostawali wyłącznie praktycy o wybitnych kwalifikacjach pedagogicznych, najlepiej po studiach wyższych. Ponadto Statut sugerował by nauczyciele przedmiotów pedagogicznych byli także w miarę możliwości zatrudnieni w szkole ćwiczeń. Byłoby to dla nich swoiste laboratorium pedagogiczne, w którym demonstrowaliby słuchaczom omawiane zjawiska pedagogiczne, a zarazem prowadzili własne badania. W Statucie zakładano, że szkoła ćwiczeń przy WSP nabierze charakteru instytucji, realizującej „pewną myśl przewodnią - dydaktyczną lub wychowawczą, promieniując rozwojem myśli i poczynań pedagogicznych nie tylko na słuchaczy, ale również na nauczycieli innych szkól powszechnych". Absolwenci WSP mieli uzyskać dwukierunkową specjalizację, niezbędną do nauczania $w$ klasach V-VIII szkoły powszechnej, połączoną z przygotowaniem do nauczania w klasach początkowych. Tak szeroki profil kształcenia zamierzano realizować poprzez wprowadzenie do programu studiów metodyk nauczania wszystkich przedmiotów, występujących w programie szkoły powszechnej.

W maju 1946 r., w Zarządzeniu Ministra Oświaty w sprawie organizacji roku szkolnego 1946/47 w szkołach ogólnokształcących i zakładach kształcenia nauczycieli ${ }^{35}$ pojawiła się zapowiedź utworzenia wyższych szkół pedagogicznych. Jako że pociągała ona za sobą likwidację państwowych pedagogiów, Ministerstwo Oświaty zaleciło, by nie przeprowadzać w nich zapisów na pierwszy rok studiów. W tym czasie rozpoczęto też powoływanie komitetów organizacyjnych WSP w tych miastach, w których przewidziano umiejscowienie siedzib tych uczelni: w Krakowie (jego przewodniczącym został prof. dr Stefan Szuman); w Gdańsku (na czele którego stanął dr Jan Schwarz, pełniący dotąd obowiązki dyrektora Pedagogium); w Katowicach (jego pracami kierował prof. dr Józef Pieter, od 1945 roku dyrektor Instytutu Pedagogicznego w Katowicach); w Lodzi (z przewodniczącą prof. dr Natalią Gąsiorowską). Zadaniem komitetów organizacyjnych bylo przede wszystkim zapewnienie powstającym szkołom niezbędnych warunków lokalowych, skompletowanie grona nauczycielskiego oraz przeprowadzenie rekrutacji na studia. Dopetnieniem działań, podjętych przez komitety organizacyjne, były decyzje ministra oświaty, powołujące do

33 E. Czernichowski, Zasady reformy ksztalcenia nauczycieli szkdl powszechnych, w: Konferencja w sprawie kszalcenia nauczycieli, odbyta w Krakowie w dniach 17, 18, 19 grudnia 1945, Warszawa 1946, 8. 131.

3. Dz. Urz. Min. Osw., 1946, nr 2, poz. 47.

is Dz Urz. Min. Ośw. 1946, nr 5, poz. 138. 
życia (1 września 1946 r.) Państwowe Wyższe Szkoły Pedagogiczne ${ }^{36}$ w Gdańsku $^{37}$, Krakowie ${ }^{38}$, Lodzi ${ }^{39}$ i Katowicach ${ }^{40}$. Ostatnia z wymienionych, z powodu trudności kadrowych i rekrutacyjnych, już w roku 1947 została przeniesiona do Lodzi i wcielona do tutejszej WSP ${ }^{41}$.

Pierwotna organizacja wyższych szkół pedagogicznych była pochodną tezy, iż ich zasadniczym celem miało być kształcenie zawodowe na poziomie wyższym kandydatów na nauczycieli szkół powszechnych. Dlatego też placówki te z założenia bardziej przypominały przedwojenne wyżej zorganizowane zakłady kształcenia nauczycieli niż szkoły wyższe. Odnosi się to zwłaszcza do ich statutowych organów kierowniczych, które tworzyli: mianowany przez Ministra Oświaty dyrektor oraz rada szkoły ${ }^{42}$. Dyrektor reprezentował szkołę na zewnątrz, organizował jej pracę i przewodniczył radzie szkoły, a ponadto był przełożonym grona nauczycielskiego, zwierzchnikiem urzędników, zatrudnionych w szkole oraz opiekunem i zwierzchnikiem słuchaczy. Natomiast radę szkoły, w skład której obok dyrektora jako jej przewodniczącego wchodzili wszyscy nauczyciele, statut WSP określał jako „władzę kolegialną szkoły w sprawach naukowych i wychowawczych”. Uchwalała ona m.in. projekty zmian w statucie, projekty programów studiów i egzaminów oraz planów organizacji studiów. Ponadto do jej kompetencji należało uchwalanie wniosków do ministra oświaty w sprawach powoływania nauczycieli - wykładowców oraz tzw. pomocniczych sił naukowych, zatwierdzanie regulaminu organizacji młodzieżowych, troska $\circ$ zdrowie fizyczne i moralne słuchaczy oraz zaspokajanie ich potrzeb bytowych (internaty, stypendia, zasilki itp.), uchwalanie preliminarza budżetowego szkoły i zatwierdzanie sprawozdań finansowych. Rada szkoły ustalała też szczegółowy podział i organizację roku szkolnego. W tym okresie rok szkolny w WSP rozpoczynał się 15 września, dzielił się na trymestry i trwał nie mniej niż 30 tygodni zajęć szkolnych ${ }^{43}$.

W pierwszych latach działalności wyższe szkoły pedagogiczne przyjęły nietypową strukturę organizacyjną. Była ona dostosowana do programu studiów, obejmującego przedmioty pedagogiczne i pomocnicze, praktykę pedagogiczną wraz z metodyką elementarnego nauczania i wybranych przedmiotów studium specjalnego oraz przedmioty studium specjalnego. Dążenie do wykształcenia absolwentów WSP w zakresie dwukierunkowej specjalizacji sprawiło, że utworzono w nich dwuprzedmiotowe sekcje. W pierwszym roku istnienia WSP zorganizowano ogółem dziesięć sekcji: w WSP w Krakowie funkcjonowały: sekcja polonistyczno-historyczna, polonistyczno-estetyczna (jej twórca i orędownik prof. S. Szuman uważał, że jej celem miało być przygotowanie nauczycieli i działaczy oświatowych do upowszechniania kultury estetycznej) i przyrodniczo-geograficzna ${ }^{44}$; w WSP w Gdańsku - sekcja przyrodniczo-geograficzna i matematyczno-fizyczna (ze względu na brak na Wybrzeżu dostatecznego zaplecza naukowego z zakresu nauk humanistycznych, a zwłaszcza odpowiednio przygotowanej kadry naukowej Ministerstwo Oświaty nie wyraziło zgody na powołanie w Gdańsku sekcji humanistycznej, a oparcie jej wyłącznie na profesorach dojeżdżających z Torunia uznano za niecelowe ${ }^{45}$; w WSP w Lodzi - sekcja filologiczno-historyczna,

\footnotetext{
${ }^{36}$ Do roku 1952 obowiqzyywała nazwa: Państwowa Wyższa Szkoła Pedagogiczna. Ostatecznie jednak upowszechniła się nazwa Wyższa Szkoka Pedagogiczna.

${ }^{37}$ Zarządzenie Ministra Oświaty z dnia 24 września 1946 r, Dz. Urz. Min. Ośw., 1946, nr 11, poz. 378.

39 Zarządzenie Ministra Oświaty z dnia 24 września 1946 r., Dz Urz. Min. Ośw., 1946. Nr 11, poz 378.

39 Zarządzenie Ministra Oświaty z dnia 24 września 1946 r, Dz. Urz. Min. Ośw. 1946, ar 11, poz. 376

40 Zarządzenie Ministra Oświaty z dnia 27 września 1946 r, Dz Urz. Min. Osw., 1945, nr 11, poz. 376.

al Wraz z uruchomieniem wyżsych szkół pedagogicznych na stanowiska ich dyrektorów powołano dotychczasowych przewodniczacych komitetów organizacyjnych. Dyrektorem WSP w Krakowie mianowano prof. dr Stefana Szumana, a jego zastępca - dr Stanisława Skalskiego, dotychczasowego naczelnika Wydziału Ksztalcenia Nauczycieli Okregu Szkolnego Krakowskiego. Prof. dr Józef Pieter został pelniącym obowiqzzi dyrektora WSP w Katowicach; dyrektorem WSP w Lodzi mianowano prof. dr Natalię Gasiorowskq zaś dyrektorem WSP w Gdańsku - dr Jana Schwarza.

${ }^{42}$ Zarządzenie Ministra Oświaty z 12 marca 1946 r. w sprawie statutu Państwowych Wyższych Szkół Pedagogicznych (Dz Urz. Min. Ośw. 1946, nr 2, poz. 47) cz. III, 8.

43 Ibidem, 28.

$44 \mathrm{Cz}$. Majorek, Z. Ruta, Powstanie i rozwoj organizacyjny WSP w Krakowie, w: Wyższa Szkola Pedagogiczna im. Komisji Edukacji Narodowej w Krakowie w latach 1946-1981, pod red. Z. Ruty, Kraków 1981, 8. 13.
} 
humanistyczna oraz przyrodniczo-geograficzna; w WSP w Katowicach - sekcja przyrodnicza i matematyczna.

Istotnych zmian $w$ strukturze organizacyjnej WSP dokonano już $w$ drugim roku ich działalności. Instrukcja o organizacji roku szkolnego $1947 / 48 \mathrm{w}$ zakresie kształcenia nauczycieli ${ }^{46}$ zobowiązała wszystkie wyższe szkoły pedagogiczne do uruchomienia kursów wstępnych, analogicznych do wstępnego roku studiów w szkołach wyższych ${ }^{47}$. Ponadto w WSP w Gdańsku utworzono sekcje humanistyczną, co było wynikiem rosnącego zapotrzebowania szkolnictwa regionu nadmorskiego na nauczycieli przedmiotów humanistycznych (głównie języka polskiego). W pewnym stopniu wynikało to także z potrzeby repolonizacji części ludności, zamieszkałej na powracających do Macierzy Ziemiach Zachodnich i Pómocnych. Natomiast w WSP w Krakowie uruchomiono sekcję matematyczno-fizyczną i polonistyczno-językową ${ }^{48}$. Ta ostatnia miała przygotowywać nauczycieli o specjalności obejmującej język polski, język rosyjski i język angielski ${ }^{49}$. Praktyka wykazała, że w trakcie 3-letnich studiów studenci nie są w stanie opanować dwóch języków obcych, w związku z czym sekcję podzielono na dwa odrębne kierunki: języka angielskiego i języka rosyjskiego. Nie przyczyniło się to wszakże w sposób wyraźny do usunięcia trudności, na jakie napotykali sluchacze. W związku $z$ tym $w$ roku następnym zrezygnowano z naboru na pierwszy rok tego kierunku studiów. Podobny los spotkał sekcję polonistyczno-estetyczną, występującą tylko w WSP w Krakowie. Mimo wielkiego zaangażowania jej twórcy, prof. S. Szumana i grona jego wybitnych współpracowników oraz bez względu na jej znaczne osiągnięcia nie zyskała ona uznania Ministerstwa Oświaty, dążącego, począwszy od roku 1947, do pełnej unifikacji WSP. W związku z tym po trzech latach funkcjonowania sekcja ta została zlikwidowana ${ }^{\text {so }}$.

Zmiany w obrębie samej idei WSP znalazły odzwierciedlenie $w$ statucie tych uczelni, w którym, na mocy zarządzenia ministra oświaty, w październiku $1947 \mathrm{r}^{51}$, dokonano pierwszej korekty. Nowy statut, potwierdzając, iż celem działania WSP jest kształcenie zawodowe na poziomie wyższym kandydatów na nauczycieli 8-klasowych szkół powszechnych, zawężał ich działalność naukową ograniczając ją do „kultywowania twórczej pracy (...) w dziedzinie praktycznej pedagogiki i dydaktyki". Zobowiazywał je także do włączenia się w proces doskonalenia czynnych nauczycieli. Nakładał ponadto na WSP obowiązek zorganizowania i prowadzenia kursów przygotowawczych dla kandydatów, którzy z różnych względów, zwłaszcza z powodu działań wojennych i okupacji, nie ukończyli szkoły średniej, uprawniającej do podjęcia studiów wyższych ${ }^{52}$. Zmodyfikowany statut zawężał też pojęcie „szkoły ćwiczeń" do przedszkola i pełnej szkoły powszechnej, realizującej w sposób wzorcowy obowiązujący program nauczania i wychowania.

Dalszych modyfikacji w sferze organizacji WSP dokonano za sprawą Instrukcji z 21 czerwca 1948 r. o organizacji roku szkolnego $1948 / 49$, która zobowiązała kierownictwo wyższych szkół pedagogicznych do podjęcia prac dostosowujących ich organizację do postanowień dekretu z 28

\footnotetext{
4s Archiwum Państwowe w Gdańsku, Materiały Wyższej Szkoły Pedagogicznej w Gdańsku (dalej: APG WSP), Odpowiedź Ministerstwa Oświaty (pismo z 20 listopada 1946 r.) na prośbe WSP w Gdańsku (pismo z 24 pażdziernika 1946 r.) o utworzenie sekcji humanistycznej, sygn. 1317/31.

* Dz Urz. Min. Ośw., 1947, poz. 132.

${ }_{47}$ Instrukcja z 19 maja 1947 r. o organizacji roku szkolnego 1947/48 w zakresie kształcenia nauczycieli szkó powszechnych; Dz. Urz. Min. Ośw., 1947, nr 6, poz. 132.

${ }^{48}$ Por.: J. Garbacik, Z dziejów Wyższej Szkoly Pedagogicznej w Krakowie (1946-1956). Cześc ogólna, w: Dziesięciolecie Wyższej Szkoly Pedagogicznej w Krakowie 1946-1956, Kraków 1957, s. 14.

${ }_{4}$ Z. Tabaka, Z dziejów Wyższej Szkoly Pedagogicznej w Krakowie (1946-1961), w: Ksztalcenie nauczycieli w Wyższej Szkole Pedagogicznej. Konferencja naukowa ku uczczeniu 15-lecia Wyższej Szkoly Pedagogicznej w Krakowie 1946-1961, Kraków 1962, s. 160.

so J. Garbacik, dz. cyt., s. 14.

si Zarzqdzenie Ministra Oswiaty z 7 października 1947 r. w sprawie zmiany Statutu WSP, Dz. Urz. Min. Ośw., 1947, nr 10, poz. 251.

s2 Ta decyzja Ministerstwa Oświaty była pochodna dekretu Rady Ministrów z 24 maja 1945 r., O utworzeniu wstępnego roku studiów w szkokach wyższych, Dz. U. RP, 1945, nr 21, poz. 122.
} 
października 1947 r. o organizacji nauki i szkolnictwa wyższego ${ }^{53}$. Dekret ten zróżnicował wewnętrzną organizację wyższych szkół zawodowych i uczelni akademickich. Zgodnie z jego postanowieniami wyższymi szkołami zawodowymi kierował rektor przy pomocy (i w zastępstwie) prorektora. Obaj byli mianowani (na trzy lata) przez ministra oświaty spośród kandydatów, zakwalifikowanych przez Radę Główną. Organem doradczym rektora była rada pedagogiczna, a w szkołach wielowydziałowych dodatkowo - rady wydziałowe ${ }^{54}$. Organem szkoły było także „zebranie ogólne”, w którym uczestniczyli samodzielni pracownicy nauki, przedstawiciele pomocniczych pracowników naukowych i administracyjnych oraz młodzieży studiującejss.

Rozciągnięcie przepisów wspomnianego dekretu na wyższe szkoły pedagogiczne spowodowało, że na początku roku szkolnego $1948 / 49$ na czele wyższych szkół pedagogicznych stanęli rektorzy, mający do pomocy prorektorów. Połączono też sekcje i przemianowano je na wydziały, a dotychczasowi kierownicy sekcji otrzymali tytuły dziekanów. Na wydziałach utworzono rady wydziału, w skład których wchodzili: dziekani, prodziekani, samodzielni pracownicy nauki oraz przedstawiciele pomocniczych pracowników naukowych, organizacji młodzieżowych, Związku Nauczycielstwa Polskiego i partii politycznych ${ }^{56}$. W zmieniającej się strukturze wyższych szkół pedagogicznych w dalszym ciągu brakowało katedr i zakładów ${ }^{57}$. Zalążkiem przyszlych zakładów naukowych stały się pracownie: biologiczne, geograficzne, fizyczne i chemiczne ${ }^{\text {sB }}$. W tym okresie były one zazwyczaj słabo wyposażone w pomoce naukowe, w zwiazku z czym przypominały pracownie dydaktyczne szkół średnich ${ }^{59}$. Właściwy rozwój zakładów naukowych w wyższych szkołach pedagogicznych nastąpił na początku lat pięćdziesiątych.

Pierwsze lata pracy wyższych szkół pedagogicznych były zatem okresem ich rozwoju strukturalnego, kształtowania się pierwszych zespołów wykładowców i tworzenia społeczności ich słuchaczy. Równocześnie były one okresem weryfikacji przyjętych założeń. Wielu bowiem zagadnień programowych i strukturalnych w 1946 r. nie rozstrzygnięto. Nie ustalono na przykład precyzyjnie miejsca WSP w strukturze szkół wyższych, zwłaszcza w stosunku do uniwersytetów; nie do końca sprecyzowano też ich koncepcje programową. Od początku ścierały się tu dwa stanowiska. Pierwsze, prezentowane przez E. Czernichowskiego, popierane m.in. przez wykładowców wywodzących się ze szkół akademickich, zakłađało, że uczelnie te, będąc udoskonaloną wersją pedagogium, miały kształcić i wychowywać nauczycieli dla wyższych klas szkoły powszechnej. Zwolennicy tego stanowiska zakładali, że przy wielkim zapotrzebowaniu na nauczycieli wszystkich szczebli niemożliwe staje się kształcenie ogółu nauczycieli na wydziałach humanistycznych i przyrodniczych uniwersytetów. Ponadto optowali oni za wyraźnym oddzieleniem metod kształcenia przyszłych badaczy (właściwych dla uniwersytetów) od metod kształcenia przyszłych nauczycieli, jako kształcenia zawodowego, w którym praca badawcza znajdować się miała na "drugim planie"

Inne stanowisko zajmowali „nieakademiccy" wykładowcy tych uczelni, związani z nimi jako pierwszym miejscem ich pracy, którzy - wychodząc z założenia, że w zakresie wykształcenia nauczycielowi szkoły powszechnej „nie należy się mniej niż innym zawodom” - opowiadali się za

${ }^{53}$ Dz. Urz. Min. Ośw. 1948 r., nr 9, poz. 449.

4 Por.: J. K. Szlapczyński, Zarzqd szkolq wyższq w Polsce Ludowej, Warszawa 1968, s. 24-25.

s5 Dz. U. RP, 1947, nr 66, poz. 415.

${ }^{56}$ M. Widernik, dz. cyt., s. 8.

${ }^{57} \mathrm{Cz}$. Majorek, Z. Ruta, dz. cyt., s. 15.

58 Z. Tabaka, Organizacja uczelni $i$ jej pracownicy, w: Dziesięciolecie Wyższej Szkoly Pedagogicznej w Krakowie 1946-1956, Kraków 1957, s. 27. Także: Notatka ze sprawozdania z wizytacji WSP w Gdańsku, przeprowadzonej przez naczelnika Wydziału Kształcenia Nauczycieli w Miaisterstwie Oświaty, Edwarda Czernichowskiego w dniach 23-26 listopada 1946 r., APG, WSP, sygn. 1317/31.

${ }^{59} \mathrm{Cz}$. Majorek, Z. Ruta, dz. cyt. s. 15; Por. także: R. Grzybowski, Okoliczności powstania Wyższej Szkoly Pedagogicznej w Gdarisku i rozwój jej infrastruktury w latach 1946-1949, „Rocznik Gdański” 1998, t. LVIII, z. I, s. $71-88$.

${ }^{60}$ Por.: Protokół z konferencji dyrektorów przedstawicieli Red Pedagogicznych Wyższych Szkól Pedagogicznych odbytej w dniach od 24-27 kwietnia 1947 r. w Ministerstwie Oswiaty, Archiwum Akt Nowych w Warszawie, Materiały Ministerstwa Oświaty (dalej: AAN Min. Ośw.), sygn. 1675. 
przekształceniem WSP w akademie pedagogiczne, wyposażone w pełnię praw akademickich. Sugerowali $w$ związku $z$ tym, aby absolwentom WSP dać pełne wykształcenia wyższe wraz z tytułem zawodowym ${ }^{61}$. Optowali też za potrzebą stworzenia im wyraźnych perspektyw ukończenia pełnych studiów wyższych. I w tej kwestii odmienne stanowisko zajmowali reprezentanci szkół akademickich, którzy zagadnienie przejścia absolwentów WSP do uniwersytetu pragneli ,pozostawić na dalekim planie”. Według nich bowiem przejście ze szkoły zawodowej do uniwersytetu powinno dotyczyć zaledwie jednostek: wszyscy absolwenci WSP powinni najpierw przez kilka lat pracować w szkole, a dopiero później najzdolniejsi spośród nich mogliby poświęcić się dalszym studiom na uniwersytecie ${ }^{62}$.

Tymczasem zmodyfikowany w 1947 r. statut WSP formalnie upoważniał absolwentów tych uczelni do kontynuowania studiów w szkołach akademickich. Czynil to jednak mało precyzyjnie, a przy tym odraczał wspomniane prawo w czasie. Rozwiązanie to było w jakimś sensie pochodna myśli E. Czernichowskiego, iż wartościowe pod względem społecznym wykształcenie zawodowe nauczycieli szkół powszechnych może być osiągnięte tylko przy zastosowaniu kilkutorowego kształcenia. Miało ono polegać na połączeniu zasadniczego wykształcenia zawodowego w zakładzie kształcenia nauczycieli z dalszym kształceniem w trakcie wykonywania praktyki nauczycielskiej ${ }^{63}$ Statut ten gwarantował ponadto absolwentom WSP pierwszeństwo przy ubieganiu się o stanowiska kierownicze w szkole i administracji szkolnej (po uzyskaniu ustalenia w zawodzie nauczycielskim) ${ }^{64}$.

Dalszy rozwój strukturalny wyższych szkół pedagogicznych uzależniony był od ostatecznych rozstrzygnięć odnośnie struktury organizacyjnej szkoły ogólnokształcącej. Stan tymczasowości, jaki zapanował $w$ omawianej dziedzinie po przejęciu ogółu spraw dotyczących oświaty przez kierownicze struktury PPR, zakończył się w pierwszych miesiącach $1948 \mathrm{r}$. W tym okresie kierownictwo PPR ostatecznie wycofało swoje poparcie dla 8-letniej szkoły powszechnej ${ }^{65}$ i opowiedziało się za modelem 11-letniej szkoły ogólnokształcącej, składającej się z 7-letniej szkoły powszechnej i 4-letniego liceum ogólnokształcącego ${ }^{66}$. Ministerstwu Oświaty zalecono zaś dokonanie, począwszy od 1 września $1948 \mathrm{r}$., stosownych korekt w strukturze systemu oświaty ${ }^{67}$.

Po reformie szkoły podstawowej z 1948 r. pojawił się problem miejsca, jakie $w$ nowych strukturach oświatowych przypadłoby wyższym szkołom pedagogicznym. Placówki te, kształcąc dotąd nauczycieli specjalistów dla starszych klas najwyżej zorganizowanych 8-klasowych szkół powszechnych, w nowych realiach stracily racje bytu. Można zatem powiedzieć, że wraz z odstapieniem władz od idei 8-klasowej szkoły powszechnej zamknął się pierwszy, niezwykle ważny etap ich rozwoju. Rozpoczął się też dla nich okres poszukiwań nowego miejsca w systemie kształcenia nauczycieli.

\footnotetext{
6! Problem tytuhu dla absolwentów WSP podnoszony był już w 1946 roku. Czlonkowie Komitetu Organizacyjnego WSP w Krakowic proponowali na przykdad nadanie absolwentom WSP tytuku "glicencjata". Niestety, zagadnienie to nie doczekało się rozwiqzania do końca okresu funkcjonowania WSP w charakterze wyższych szkól zawodowych.

62 Czlonkowie Komitetu Organizacyjnego WSP w Krakowie stali na stanowisku, ze absolwenci WSP powinni mieć prawo ukończenia studiów uniwersyteckich po 3-letniej praktyce szkolnej, AAN Min. Ośw., Pismo Komitetu Organizacyjnego w Krakowie do Ministerstwa Oświaty z 8 czerwca 1946 r., sygn. 1673.

69 W modelu tym pierwsza faz̨̧ stanowila wyższa szkola pedagogiczna (względnie liceum pedagogiczne), druga - 2-3 letni okres praktyki zawodowej w szkole powszechnej przed ustaleniem w zawodzie, trzecia - uzupetniające studia uniwersyteckie lub kursy administracji szkolnej (a w przypadku absolwentów liceów pedagogicznych ksztakenie uzupetniające w WKN-ach lub Instytutach Pedagogicznych).

Według Ministerstwa Oświaty moglo to nastąpić po 2-3-letnim okresie praktyki zawodowej w szkole powszechnej Por.: E. Czernichowski, Prace Ministerstwa Oswiaty w zakresie ksztalcenia nauczycieli w Polsce. Referat wygkoszony podczas obrad Walnego Zjazdu Sekcji Zakładów Kształcenia Nauczycieli ZNP (12 - 13 maja 1947 r.), Biuletyn Sekcji Zakładów Kształcenia Nauczycieli Zarządu Glównego ZNP, AZG ZNP, sygn. 719.

65 Por.: S. Mauersberg, Reforma szkolnictwa, s. 210-211.

6. Bieńkowski, Problemy polityki kulturalnej, „Nowe Drogi", 1948, nr 7, s. 81.

67 Ministerstwo, stwierdziwszy, że, ,(...) jednolita szkoła ogólnokształcąca stopnia podstawowego i licealnego jest w zakresie pierwszych swoich 7 klas obowiqzzową szkołą podstawową (...)" upowszechniło też nazwę nszkoła podstawowa". Por.: J. Jakubowski, Polityka oświatowa Polskiej Partii Robotniczej 1944 - 1948, Warszawa 1975, s. 250 .
} 
Początkowo Ministerstwo Oświaty zamierzało dostosować WSP do roli zakładu kształcenia nauczycieli szkół podstawowych. W tym celu zapowiedziało nawet skrócenie okresu studiów w WSP do lat dwóch. Projekt ten, zakładając pozostawienie WSP $w$ strukturze zakładów kształcenia nauczycieli szkól podstawowych, w praktyce oznaczał ich zrównanie z liceami pedagogicznymi. Nic zatem dziwnego, że nie zyskał akceptacji rektorów, prorektorów i delegatów rad pedagogicznych wyższych szkół pedagogicznych ${ }^{68}$. Opowiedzieli się oni nie tylko za utrzymaniem tych uczelni w dotychczasowej postaci, ale również za ich strukturalna i programową ewolucją ${ }^{69}$. Alternatywą wobec całkowitej likwidacji WSP stało się przekształcenie ich w zakłady kształcenia nauczycieli szkół średnich. Ostateczne decyzje w tej kwestii Ministerstwo Oświaty poprzedziło serią konsultacji z kierownictwem i wykładowcami poszczególnych uczelni, przeprowadzonych na przelomie marca i kwietnia 1949 r. Ministerstwo oczekiwało odpowiedzi na dwa pytania. Pierwsze z nich dotyczyło warunków, na jakich absolwenci WSP mogliby ubiegać sį̧ o stopień magistra filozofii na uniwersytetach. Chodziło o określenie zakresu studiów uzupebniających, zwłaszcza ćwiczeń praktycznych, jakie absolwenci WSP powinni odbyć w pracowniach i laboratoriach. Pytanie drugie dotyczyło możliwości rozszerzenia uprawnień absolwentów WSP do nauczania w całej jedenastoletniej szkole ogólnokształcącej ${ }^{70}$.

Stanowisko wykładowców WSP, w myśl którego spełnienie wymienionych warunków wymagało m.in. skorelowania programu studiów w WSP z programami pierwszego stopnia studiów uniwersyteckich, zatrudnienia w charakterze wykładowców WSP większej liczby profesorów szkół akademickich oraz przeprowadzenia zmian w planach studiów WSP poprzez wyodrębnienie głównego przedmiotu studiów oraz przedmiotu pobocznego, niewątpliwie przyspieszyło decyzję władz oświatowych o zmianie uprawnień absolwentów WSP. Jednakże, jak się wydaje, jej nie przesądziło. Właściwych przesłanek tej decyzji szukać należy bowiem poza wyższymi szkołami pedagogicznymi. Wymienić tu należałoby wyraźne - zwłaszcza po 1948 I. - dążenie PZPR do ukształtowania nowej inteligencji o robotniczo-chłopskim rodowodzie, a także próby zmiany, przy pomocy szkoły i nauczyciela, świadomości narodu polskiego, czy też zamiar kształtowania młodzieży w oparciu o przejęte z ZSRR ideały wychowawcze komunizmu. Obok nich niebagatelną role odegrały czynniki polityczne i ekonomiczne, w tym niedostateczna liczba absolwentów uniwersytetów, podejmujących prace $w$ szkołach średnich.

Pomijając w tym miejscu głębszą analizę wymienionych uwarunkowań stwierdzić należy, iż wraz z zarządzeniem ministra oświaty z 28 czerwca 1949 r. o zmianie uprawnień absolwentów wyższych szkół pedagogicznych ${ }^{71}$, w systemie kształcenia nauczycieli pojawił się nowy, liczący się podmiot Odtąd bowiem dyplom ukończenia WSP uprawniał do nauczania w szkołach ogólnokształcących stopnia podstawowego i licealnego oraz $w$ zakładach kształcenia nauczycieli. Ta kontrowersyjna decyzja zadecydowała o kierunku rozwoju wyższych szkół pedagogicznych w kolejnych okresach ich działalności. Stała się też przyczyną licznych ataków przeciwników kształcenia nauczycieli szkół średnich poza uniwersytetami. Przerwała ona przy tym swoisty eksperyment pedagogiczny, istotą którego była pierwsza w dziejach oświaty polskiej próba masowego kształcenia nauczycieli szkół powszechnych na poziomie wyższym. Do idei tej powrócono dopiero po kilkunastu latach, za sprawą tworzonych pod koniec lat sześćdziesiątych wyższych szkół nauczycielskich.

Podsumowując przedstawione rozważania należy podkreślić, że geneza wyższych szkół pedagogicznych jest wypadkową zarówno dążeń nauczycielstwa polskiego, przez wiele dziesięcioleci, jeśli nie wieków, wytrwale dopominającego się o wyższe wykształcenia dla nauczycieli szkół powszechnych, jak i uwarunkowań polityczno-społecznych, towarzyszących rozwojowi systemu

\footnotetext{
69 J. Jarowiecki, Ksztalcenie nauczycieli w wyższych szkolach pedagogicznych, s. 207

(6) Por. J. Garbacik, dz. cyt., 17.

70 APG, WSP, Pismo Ministerstwa Oświaty z 30 marca 1949 (Nr II KN-1738/49) syen 1317/39

${ }^{71} \mathrm{Dz}$. Urz. Min. Ośw., 1949, nr 10, poz. 182.
} 
kształcenia nauczycieli w PRL. Ich koncepcja, zaledwie zarysowana w 1946 roku, była systematycznie rozwijana i doskonalona w kolejnych latach. Można zatem powiedzieć, że lata 1946-1949 to okres „stawania się" wyższych szkół pedagogicznych jako zakładów kształcenia nauczycieli dla wyżej zorganizowanych szkół powszechnych.

Jan Hellwig

Poznań

\section{Ksztalcenie nauczycieli w Studium Nauczycielskim Nr 1 w Poznaniu ${ }^{1}$}

Postulaty w zakresie kształcenia nauczycieli w jednolitych szkołach wyższych, także o charakterze akademickim, mają na gruncie polskim wieloletnią tradycję ${ }^{2}$.

Okres powojenny charakteryzowal się różnorođnością form kształcenia nauczycieli mających na celu zaspokojenie przede wszystkim potrzeb ilościowych. Dominującą rolę odegrały w tym zakresie licea pedagogiczne (LP), które w latach 1945-1954 były w zasadzie głównymi zakładami kształcenia nauczycieli ${ }^{3}$. Cieszyły się one dużą popularnością. Perspektywa nowoczesnej i wysoko zorganizowanej szkoły podstawowej wskazywała jednak na konieczność podniesienia poziomu wykształcenia nauczycieli. Nie udało się tego osiągnąć przez zmiany w profilu liceum pedagogicznego, do którego wprowadzono liczne specjalizacje. Przygotowanie pedagogiczne $\mathrm{i}$ przedmiotowe do zawodu oparte było $w$ nich jednak na niskim poziomie wiedzy ogólnej kandydatów, których rekomendowano do tych szkół po siedmiu klasach szkoły podstawowej. Zbyt krótki, czteroletni okres kształcenia w liceach pedagogicznych, uniemożliwił należyte opracowanie materiału ogólnokształcącego i pedagogicznego. Jak wskazuje Wacław Wojtyński, przeprowadzone jesienią 1953 r. badania nad pracą młodych nauczycieli - absolwentów liceów pedagogicznych - wykazały bardzo istotne braki w ich przygotowaniu do zawodu 4 .

Splot wielu czynników politycznych, spolecznych i pedagogicznych, spośród których warto wyeksponować przynajmniej dwa, wpłynęły na decyzje rządu PRL ○ powołaniu do życia w pewnym sensie nowych zakładów kształcenia nauczycieli, jakimi były studia nauczycielskie. Do czynników tych należały po pierwsze potrzeby doskonalenia systemu szkolnego przez podniesienie poziomu kształcenia nauczycieli, a po drugie pozyskanie nowych aktywistów frontu ideologicznego, za jakich uznawano nauczycieli, wykształconych w zakładach wzorowanych na modelu radzieckim.

Pierwsze studia nauczycielskie zorganizowane zostały z dniem 1 września 1954 r. w siedmiu ośrodkach: w Katowicach, Kielcach, Olsztynie, Poznaniu, Raciborzu, Szczecinie i Toruniu. Powołanie do życia tych zakładów kształcenia nauczycieli było wynikiem kompromisu pomiędzy postulatami nauczycielstwa a możliwościami państwa.

\footnotetext{
s. $45-55$.

${ }^{1}$ Por. J. Hellwig, Studia Nauczycielskie w Poznaniu (1954-1971), „Kronika Miasta Poznania” 1973, nr 2,

${ }^{2}$ Por. J. Hellwig, Wklad Zwiqzku Nauczycielstwa Polskiego w ksztalcenie i doksztalcanie nauczycieli w Polsce w latach 1919-1968, Poznań 1973, passim.

${ }^{3}$ B. Ratuś, Licea pedagogicze w Polsce Ludowej. 1944 -1970, Warszawa - Poznań 1974, passim.

4 W. Wojtyński, O ksztalceniu naucz yciela szkoly podstawowej w Polsce i na świecie, Warszawa 1971, s. 105.
} 